\title{
REgulation of Triage IN Times of A PANDEMIC: EXPERIENCES FROM SLOVENIA (AND BEYOND)
}

\author{
Accepted \\ 09. 07. 2021 \\ Revised \\ 17. 08.2021 \\ Published \\ 29. 10. 2021 \\ Luka Mišič \& Grega Strban \\ University of Ljubljana, Faculty of Law, Ljubljana, Slovenia. \\ E-mail: luka.misic@pf.uni-lj.si, grega.strban@pf.uni-lj.si \\ CORRESPONDING AUTHOR \\ luka.misic@pf.uni-lj.si
}

Keywords

triage,

Covid-19,

patients'

rights,

human

dignity,

equal

treatment

\begin{abstract}
The article offers an overview of legal regulations governing (medical) triage in Slovenia and their importance in times of the Covid-19 epidemic. Focusing on the Patients' Rights, Health Care and Health Insurance, Medical Services, and Health Services Act, it looks at ways in which legal rules and medical standards intertwine when it comes to deciding who should receive particular limited medical treatment first or in what order. It also deals with ways in which professional rules of conduct or medical standards may, on the one hand, exclude the unlawfulness of particular conduct, and how, on the other hand, law may limit the autonomy of medical practitioners. Both the autonomy in their professional conduct as well as healthcare providers', but especially professional organizations' law-making autonomy. Even if grounded in the Slovenian legal order, the present article by nature surpasses its domestic boundaries, since the Covid-19 epidemic created similar issues in several if not in all European jurisdictions. Even more so, since the article addresses several general challenges concerning triage in times or moments of crisis, such as state's positive obligations, recognition of patients' private autonomy, medical treatment abroad, ethical deliberations concerning a just distribution of scarce medical services, etc.
\end{abstract}




\section{$1 \quad$ Introduction}

The notion of (medical) triage is best described as a process of determining the priority of competing patients when accessing particular limited medical treatment (for example, a particular medical service, equipment, drug, even vaccination) according to the criteria of need or the severity of their medical condition and the probability of their successful recovery. It forms part of (mostly public) doctors' every day routines, for example, in cases of patients being referred by their GPs to particular specialists. Article 2(20)(b) of the Patients' Rights Act (Zakon o pacientovih pravicah, ZPacP), ${ }^{1}$ accompanied by Article 14(b), for example only refers to the notion of triage within the particular meaning of a referral document, issued under the following degrees of priority: (a) urgent, (b) very fast, (c) fast, (d) regular. The referring physician determines the degree of priority. Next to his professional opinion, he has to consider modern medical guidelines, the patient's best interest and the reasonable time of referral. According to Article 14(b)(5) of the Patients' Rights Act, the minister of health prescribes maximum waiting periods for particular medical treatment. ${ }^{2}$

At a glance, triage might appear as being governed principally by the medical profession's rules or doctors' professional opinion on who, when and under what medically justified conditions should receive particular medical treatment. However, it is also shares a profound link to law, since postponement or non-provision of particular medical treatment might not only represent a breach of patients' and insured persons' legal rights but may also interfere with their private autonomy and with constitutionally guaranteed categories of human dignity and safety, as enshrined in Article 34 of the Slovenian Constitution. ${ }^{3}$ Textbook examples of triage namely consist of the hardest cases in which particular medical treatment is withdrawn for a previously entitled patient as to allow for medical treatment of a new patient, having a better outlook for successful recovery. Such examples mirror the distinction between expost and ex ante competition (expost and ex ante triage) of patients, whilst opening tough questions of unlawfulness of conduct and culpability or guilt of medical professionals within the realm of both criminal and civil law. However, even

\footnotetext{
${ }^{1}$ ZPacP, Official Gazette of the RS, No. 15/08 to 177/20.

${ }^{2}$ Rules on the referral of patients, the management of waiting lists, and the maximum permissible waiting times, Official Gazette of the RS, No. 3/18 to 103/21.

${ }^{3}$ Constitution of Slovenia, Official Gazette of the RS, No. 33/91-I to 92/21.
} 
less demanding cases of triage may raise questions of civil and criminal liability. In such cases, the relationship between heteronomous legal rules passed by the State and autonomous rules of the medical profession is key as to determine whether deferral, non-provision or even withdrawal of medical treatment was either (a) lawful, (b) unlawful but no culpability can be ascribed, or (c) unlawful with ascribed culpability. The limits of autonomy, provided by law to the medical organizations and their rule-making powers or to practitioners, can, if set to narrowly, have a strong impact on the emergence of defensive medicine but might, if set to broad, lead to the prevalence of medicine over law and its basic values such as human dignity, equality and legal certainty. Some of these and other values, like the respect for one's autonomy, life and well-being, are of course common to both professions, legal and medical ones, and their set of values but might be subject to varying degrees of restriction depending on who has the final say. Even so, Korošec and others (2009: 50) note that the respect for the individual and his or her physical and mental integrity form the central provisions of the Slovenian code of medical ethics, ${ }^{4}$ according to which doctors, providing medical treatment, are bound to respect patients' (human) dignity. It is, however, important to note that no patients' obligations can be derived from the said or any other medical professions' code. Codes, being sources of autonomous law, only bind doctors (and other medical staff) as members of the medical profession or chamber.

\section{The Starting Point: Legally Determined Social Relations in Healthcare}

As with many other societal relations, those in healthcare are legally regulated. Their main purpose is to guarantee all forms of access to high quality healthcare to everyone. At their core lies the social insurance relation between the insurance carrier, such as the Health Insurance Institute of Slovenia (Slov. Zavod za zdravstveno zavarovanje Slovenije, ZZZS, hereinafter: HIIS), and the socially insured person (principally the insured and his/her insured family members), since the majority of healthcare is publically financed. ${ }^{5}$ The insurance carrier has to provide healthcare to

\footnotetext{
${ }^{4}$ Kodeks zdravniskee etike from 1992, last amended in 2016, available at https://www.zdravniskazbornica.si/docs/default-source/zbornicni-akti/kodeks-2016.pdf?sfvrsn=2 (access 9 July 2021).

572 percent of healthcare expenditure in Slovenia was public in 2018. See the yearly report of the Health Insurance Institute of Slovenia for 2020, available at https://www.zzzs.si/o-zzzs/letno-poslovno-porocilo/ (access 9 July 2021).
} 
socially insured persons and is entitled to receive contributions. Conversely, the principally insured person is obliged to contribute and has (together with his or her family members) the right to healthcare. Other legal relations might be attached to this undoubtedly public legal relation. This includes, for example, the relationship between the health insurance carrier and the insured person's employer who has to pay social security contributions as well, and in several countries, with the tax administration, responsible not only for collecting taxes, but also social insurance contributions.

However, the insurance carrier does not provide healthcare in-kind itself. Therefore, relations with medical providers have to be legally regulated as well. Although individual contracts are concluded between the HIIS and medical providers, they are more of a public than private legal nature. ${ }^{6}$

What is most interesting concerning the topic of triage is the legal regulation of the relation between a socially insured patient and medical providers, contracted by the HIIS. Historically, the patient-physician relationship was considered a private, civil law relationship of demand and supply between a patient or costumer and service provider. Moreover, the physician committed him/herself to provide healthcare to the individual and the patient rewarded such effort (i.e. through remuneration). At first, such relation was not perceived as synallagmatic, i.e. producing obligations on both parties. The notion of honorarium stems from Roman law. Healthcare was provided as an honour (Lat. honeste) and without demanding any payment. In the forefront of the medical art was the wellbeing of patients and not making money. In fact, Roman physicians were awarded voluntary payment, a so called honorarium (Gurgel 2000: 5).

Today, this very personal (Lat. intuitu personae) relationship can be perceived as a private one, for example as a contractual relationship between the insured person and a service provider to the financial burden of the insurance carrier, or as contractual relationship between the insurance carrier and the medical provider to the benefit of a patient. Some, however, argue that the relation between socially

\footnotetext{
${ }^{6}$ It is, for example, legally determined who shall conclude a contract, what its substance should be, what are the consequences if a new contract is not concluded in time and how disputes shall be solved (with mandatory, hence public arbitration procedure). See Articles $63 \mathrm{ff}$. of the Health Care and Health Insurance Act (Zakon o zdravstvenem zavarovanju, ZZVZZ), Official Gazette of the RS, No. 9/92 to 51/21.
} 
insured patients and physicians is a public one, regulated mainly by public law. Of course, this does not exclude the non-contractual civil relationship in case of damages. Since the patient-physician relationship is legally construed, it is also essential that physicians remain within the boundaries of internationally recognised medical science when executing a medical treatment plan in order to achieve one of the treatment goals (i.e. recognising a disease, cure it, prevent deterioration of health and alleviating pain). Therefore, clinical guidelines have to be clearly recognisable (in written form), also for the courts of law to determine whether treatment was provided with due diligence and within the scope of the lege artis standard. ${ }^{7}$ Hence, the substance of the patient-physician relationship is governed by internationally recognised medical science. Moreover, various codes of conduct can be of assistance when legally evaluating medical behaviour. Historically, they range from the Hippocratic Oath - parts of which seem questionable today -, and Maimonides' ethics, to more contemporary declarations of the World Medial Association (WMA). They govern the patient-physician relationship in general and in more specific ways and apply not only when treating children, people with disabilities, patients requesting euthanasia, treating issues of reproductive medicine, or HIV/AIDS, but also when treating Covid-19 patients. According to Slovenian legislation, in all cases the necessity of treatment, and no other personal circumstance, is considered the only priority. 8

However, if different medical codes of conduct foresee certain behaviour, why is legal regulation even necessary? Is it not physicians who know best how to treat their patients? Clearly. However, law is also required to restrain human nature. Without dwelling on the interplay between law and morality, we could recognise that medical practises of refusing medical treatment to persons over a certain age (anecdotal evidence might indicate that Covid-19 patients over the age of 85 were not treated at all) would be against the fundamental legal (constitutional) principles of equal treatment and non-discrimination. Special medical procedures might be required for elderly and there is a specific field of medicine (gerontology) dealing with aging. Straightforward denial of treatment purely on grounds of age is legally inadmissible.

\footnotetext{
${ }^{7}$ See Article 3 of the Medical Services Act (Zakon o zdravniški službi, ZZdrS), Official Gazette of the RS, No. 98/99 to $66 / 19$.

${ }^{8}$ See Article 45 of the Health Services Act (Zakon o zdravstveni dejawnosti, ZZDej), Official Gazette of the RS, No. $9 / 92$ to $203 / 20$.
} 
In a post-paternalistic patient-physician relationship, cooperation and active partnership of both is required. Not only the physician's, but also the patient's autonomy, must be respected. Both are firmly rooted in numerous legal obligations entailed in legislative acts and the Constitution. The patient is considered a "captain" of his/her life and his/her will (i.e. consent) at the time of treatment (even if expressed before the treatment) is essential. The patient's relatives may be consulted, but they do not form part of the decision-making legal process, unless they possess legal custody of the patient.

Medical practitioners should have substantial discretion for making their concrete decisions in the internationally recognised medical science (with clear clinical guidelines at hand) and in legal rules taking the medical profession's expertise into account via the key lege artis professional standard adopted by law. The burden of decision-making in a concrete case should not be left to the physician alone. It might be too heavy to carry. Moreover, no one, not even medical doctors, can rationally decide in their own affairs (lat. in causa sua) and shall be excused from such cases, which is for example crystal-clear for lawyers and legal proceedings.

\section{Law and Its Deontological Commitments and Constraints}

A mere glimpse at the Health Care and Health Insurance Act (Zakon o zdravstvenem varstu in zdravstvenem zavarovanju, ZZVZZ), ${ }^{9}$ the Patients' Rights Act, the Medical Services Act and the Health Services Act, reveals Slovenian legislation as being generally grounded in the idea of a categorical protection of human dignity and safety, protecting the individual or the self from being (mis)used to advance the goals of another person. Meaning, every non-provision or postponement of medical treatment could be deemed unlawful when causing any relevant harm to the patient. This is true even if, under a utilitarian calculation, such harm is caused in order to prevent an even greater harm, be it to another individual or the aggregate harm to several persons. A similar conclusion could be derived from Article 2 (Primacy of the human being) of the Convention on Human Rights and Biomedicine (the Oviedo Convention), which stipulates that the interests and welfare of the human being shall prevail over the sole interest of society or science. That is if the notion of buman being is interpreted as the individual and if the interests of the society also

${ }^{9}$ Official Gazette of the RS, No. 9/92 to $51 / 21$. 
encompass examples of promoting aggregate utility at the level the level of a particular society. However, some domestic provisions allow for a more relativized approach to the matter at hand.

If on the one hand, the Health Care and Health Insurance Act stipulates that every person possesses a right to the highest attainable level of health, and if the Patients' Rights Act on the other hand defines appropriate medical treatment as medical treatment, which is in line with the needs of the patient and the capabilities of the Slovenian health care system. ${ }^{10}$ Similarly, Article 3 of the Oviedo Convention stipulates that parties, taking into account health needs and available resources, shall take appropriate measures with a view to providing, within their jurisdiction, equitable access to health care of appropriate quality. Concerning both the Oviedo Convention and the Patients' Rights Act, a similar question emerges - can the condition of capabilities or available resources be interpreted in a way as to allow a straightaway, almost automatic lowering of standards midst an epidemic? This would mean that deferral or non-provision of particular medical treatment or the provision of medical treatment of a lower quality would not necessarily represent a breach of professional medical standards or rules of conduct and would be considered lawful from this perspective. According to Ivanc (2011: 829), the right to health, as established in international law, cannot be dependent upon the lack of financial or other resources. From this point of view, additional resources should be provided in times of an epidemic so as to allow healthcare and health insurance systems to function properly. Such obligation can, even in times of an epidemic, still be derived from Article 50(2) of the Slovenian Constitution, stipulating that the state shall regulate compulsory health, pension, disability and other social insurance, and shall ensure its proper functioning (Mišič, 2020: 3). Such obligations of course do not relate to medical practitioners" conduct, but rather to the conduct of the state in relationship to the public healthcare network and its health insurance carrier.

Moreover, a solution when the national healthcare system is not able to provide (geographically, timely, financial, procedural or informational) access to healthcare, all kinds of access stemming also from Article 51 of the Slovenian Constitution (Strban 2005: 86), should be sought in the EU law on cross-border healthcare

\footnotetext{
${ }^{10}$ Compare Article 2(1) of the Health Care and Health Insurance Act and Article 11(2) of the Patients' Rights Act.
} 
(Strban 2013). Coordination of social security systems, ${ }^{11}$ including mandatory health insurance or national health service, has been established for the purpose of public healthcare systems cooperating with each other, when they alone cannot provide high quality healthcare in due time. The (poor) situation of the existing national public healthcare system can hardly present an excuse, ${ }^{12}$ since the CJEU has harmonised, at least to a certain extent, the standard of healthcare. What is deemed usual or standard in the professional circles concerned cannot be evaluated only nationally, but has to respect the international medical science and healthcare that is sufficiently tried and tested internationally. If such treatment cannot be provided in due time in the Member State concerned, the right to authorised cross-border medical treatment, which is also discussed in the following paragraphs, has to be granted. ${ }^{13}$

The Patients' Rights Act itself applies both to mandatorily insured as well as private patients seeking medical treatment outside the public healthcare network. The Act also stipulates the right to obtain medical treatment from public funds, as does the aforementioned Article 51 of the Constitution. Article 12 of the Patients' Rights Act mandates the right to such treatment when the latter is medically justifiable and when it is expected that it is to the greatest benefit to the patient, i.e. that the benefits of such treatment outweigh the associated risks and burdens for the patient. The Medical Services Act takes a similar approach. Its Article 3, for example, provides for doctors' professional autonomy, stipulating that every doctor freely decides on the method of treatment deemed most appropriate under the given circumstances. What links the said provisions of both legislative acts is the fact that they on the one hand take into account circumstances of a particular case whilst on the other hand give autonomy to medical practitioners. However, as observed by Korošec and others (2009: 49), Article 3 of the Patients' Rights Act provides for a set of key legal principles like the protection of persons' physical and mental integrity, private autonomy and privacy. Among them, the protection of human dignity provides for the patient's autonomy and represents the most important principle, which has to be considered especially by medical practitioners and administrative and criminal justice. Briški and others (2020: 183) recognize the argument of human dignity as

\footnotetext{
${ }^{11}$ Regulation (EC) 883/2004 on the coordination of social security systems, OJ L 16630.4 .2004 with amendments and its implementing Regulation (EC) 987/2009, OJ L 284, 30.10.2009 with amendments.

12 C-268/13 - Petru, EU:C:2014:2271.

${ }^{13}$ CJEU decision in case C-157/99 - Smits and Peerbooms, EU:C:2001:404.
} 
one of the strongest tools of legal argumentation but at the same time warn of its commonly partial use.

Possibly the best legislative example of a rather complex relationship between human dignity protection and professional autonomy, indirectly encompassing the assessment of every individual case with all of its medically relevant circumstances, stems from the aforementioned Article 45 of the Health Services Act. The latter stipulates that medical professionals perform their duties in accordance with accepted medical doctrine, the medical deontology code and other professional and ethical codes. However, they ought to treat all persons (patients) equally, whilst respecting their constitutional and legal rights. The only criteria for priority of medical treatment is its necessity, i.e. the urgency of the medical procedure. It seems that direct reference to patients' constitutional and legal rights, such as the right to appropriate, quality and safe medical treatment, enshrined in Article 11 of the Patients' Rights Act, puts us back at the beginning of the discussion. Similarly, Article 7 of the Patients' Rights Act prohibits unequal treatment of patients on grounds of sex, ethnicity, disability, age, etc. or any other personal circumstance. This means that any patient, with a particular medical condition, has the right to equal access to healthcare in relation to other patients, sharing the same medical condition. Otherwise, it would have been the personal circumstance of a given medical condition that would represent the grounds of unequal treatment. Even so, a patient, either a private patient or a mandatorily insured person, does not possess the right to particular medical treatment, meaning a right to choose the exact method of treatment. According to Article 21 of the Patients' Rights Act, the patient has the right to actively partake in the process of selecting medical treatment. However, the patient can only choose freely the exact method of treatment when the doctor or consortium of doctors offering medical care presents alternatives, all professionally deemed appropriate, quality and safe, according to Article 11 of the said Act. In cases of disagreement, the patient may invoke the right to a second opinion under Article 40 of the Patients' Rights Act. The invocation of this right, however, seems limited to cases met by an abundance of time, not hard cases of triage. In such cases, there even might not be enough time for the patient to deny (i.e. give informed consent to) the provision of medical treatment, for example, the patient's connection to a medical ventilator, surgery, under Article 30 and 31 of the Patients' Rights Act if no prior refusal was given. Paradoxically, hard cases of triage might also lead to violations of patients' private autonomy and (human) dignity in cases in which 
unwanted, but urgent medical care was provided and the patient lived. That is in cases where prior refusal of treatment was not showcased by the patient or noticed at the exact moment of treatment by the medical staff.

What happens, however, in far more plausible (i.e., everyday) cases when two or more patients claiming medical treatment display the same or nearly the same medical needs, which can be met only if the same urgent but scarce treatment is provided for all at once? It seems that conventional legal institutions or, better still, rights and obligations enshrined in basic health and health insurance legislation cannot be of much assistance. Their human dignity commitments, inextricably linked to equal treatment and private autonomy protection, also represent their somewhat insurmountable constrains of an effective practical application. Should the law in hard cases thus make way for medicine to take over? Not just yet. Article 15(3) of the Slovenian Constitution allows, as is common practice with the collision of constitutional rights, for human rights and fundamental freedoms to be limited (only) by the rights of others and in cases, provided by the Constitution. Similarly, Article 4(4) of the Patients' Rights Act allows for the limitation of patients' rights when rights of others could be at risk and if stipulated by public health and safety legislation, for example, the Communicable Diseases Act (Zakon o nalealjivih boleznih, ZNB) $\cdot{ }^{14}$ Even so, hard cases of triage do not necessarily call for acts of constitutional or other balancing of legal rights, especially rights of a different status. They call for decisions on who gets to live and who gets to die (and why).

\section{Suspension of Medical Services: A Particular Form of Triage with Particular Consequences}

According to John Hopkins University, Slovenia, a country of roughly two million residents, so far experienced 257,252 confirmed Covid-19 cases, 4,419 Covdid-19 related deaths or 211.64 deaths per 100,000 inhabitants. ${ }^{15}$ What is striking is the fact that Slovenia was among the European countries best coping with the virus during the initial period of the epidemic but among those barely managing to prevent the spread of virus during its the second period. Even with the high numbers of confirmed Covid-19 cases and Covid-19 related deaths, there exist no (public) records of cases in which medical practitioners faced hard cases of medical triage in

\footnotetext{
14 Official Gazette of the RS, No. 33/06 to 82/21.

15 https://coronavirus.jhu.edu/data/mortality (access 30 June 2021).
} 
which life and death decisions entered the wards. Even more so, the public healthcare network (after all preventive measures failed) seems to have proved resilient enough to handle the epidemic as it occurred during the first, very mild wave in the spring of 2020 and during the second, much more devastating wave inbetween autumn of 2020 and spring of 2021. However, the true toll of the epidemic still awaits to be revealed. The majority of non-urgent medical services were namely suspended during the first and a part of the second wave of the epidemic. The goal was on the one hand to carry out a more effective fight against the disease, with additional capacities, staff, medical equipment, etc., earmarked for Covid-19 patients and, on the other hand, to prevent additional spread of the disease. According to the World Health Organisation (2020: 2), all countries were making difficult decisions to balance the demands of responding directly to the Covid-19 epidemic with the need to maintain the delivery of other high-quality essential health services under equitable access conditions as to limit direct and avoid indirect mortality.

In a broader sense, any suspension of (all non-urgent) medical services should also be considered as a form of triage, since it determined the priority of competing patients in accessing particular medical treatment. Even more so, potential and nonidentified, covid-19 related patients, might have been given general priority over actual, covid-19 non-related patients. The suspension of medical services (and the right to health, the right to equal access to healthcare, the right to appropriate, quality and safe medical treatment, etc.) is an obvious example of how patients' rights can be limited on grounds of public health and safety legislation or for the sake of protecting rights of others. It is also an obvious example of how constitutional rights, i.e. human rights and basic freedoms, can be limited on grounds of a legitimate, valid reason, such as public health protection, if meeting other criteria of the proportionality test. At the same time, mandatorily insured persons experienced a suspension of their health benefits in kind, which should have been provided within a two-sided social insurance relationship in which social security contributions were paid. The suspension of some and the increase of other medical programmes might also lead to complex reimbursement or compensation claims between medical providers and the HIIS. Any deferral of medical treatment can also lead to a later increase of healthcare-related costs, both on the part of the patient and his private expenditure as well as on the part of the health insurance carrier. 
A deferral also increases waiting periods for particular medical treatment, calling for new processes of determining the priority of competing patients on grounds of their referral documents, issued by their GPs or referring specialists. Going back to the increase of patients' public expenditure, the act of triage, when the reasonableness of the waiting period for particular medical treatment is not considered, may lead to restrictions concerning access to public healthcare. Put differently, in cases of long waiting periods, socially insured persons are more inclined towards claiming particular medical services as private patients within the private healthcare network, possibly returning to the public network to claim complex and expensive services, such as surgery or complex therapies. This possibility is of course reserved for socially and economically privileged insured persons, who possess the knowledge and material means of obtaining treatment with private physicians, either at home or abroad. In the latter case, when claiming treatment according to Directive $2011 / 24 / \mathrm{EU}$ on the application of patients' rights in cross-border healthcare, ${ }^{16}$ they may even obtain full or at least partial reimbursement of private healthcare costs from the national (Slovenian) social insurance carrier.

Such obtainment of medical care is even more profoundly linked to patients' knowledge, not only on rights, granted by national but also by EU law provisions, knowledge on how and where to find the appropriate specialist abroad, and the material means needed for travel, stay and up-front pay of provided medical services. After things cool down, it will be interesting to see whether the numbers of Slovenian insured persons claiming medical treatment abroad on grounds of the Directive, on grounds of Regulation (EC) No 883/2004 on the coordination of social security systems and the associated Article 44b of the Health Care and Health Insurance Act, will increase. ${ }^{17}$ Next to its Article 44b and Article 44c, which represents a transfer of the said Directive into the Slovenian legal order, the Health Care and Health Insurance Act also provides of a purely domestic provision giving right to obtaining medical treatment abroad, i.e. anywhere in the world, if options of successful medical treatment in Slovenia have been exhausted. In such cases, after obtaining prior approval, the mandatorily insured person is referred to a specific healthcare provider with full coverage of direct and indirect costs of treatment, like travel costs. However, the said provision covers cases in which methods of treatment abroad exceed those available in Slovenia. The provision does not apply due to

\footnotetext{
${ }^{16}$ OJ L 88, 4.4.2011.

${ }^{17}$ For cross-border healthcare in times Covid-19 see Mišič \& Strban (2021: 973 ff.).
} 
waiting periods or, for that matter, any deferral of medical services, but mostly since they are deemed more advanced or are, for whatever other reason (for example, the rarity of the disease or medical condition), not available in Slovenia.

The act of suspension is thus also linked to the question of positive duties of the State. This is true not only in regard to immediate but also the long-term increased medical needs of the population, which are further aggravated due to the prolonged waiting periods. According to Ivanc (2011: 829), contemporary international law considers the right to health [in Slovenia for example derived from Article 51 of the Constitution, stipulating the Right to Health Care] not as an end-state right, for example, the right to be healthy, but as a right grounded in positive State obligations. Considering the suspension of (non-urgent) medical services, the State, on the one hand, has the obligation of preventing the spread of the virus, and, on the other hand, has to prevent death and relevant deterioration of health for all mandatorily insured persons and even private patients, regardless of their medical condition's link to Covid-19. Time and suits for damages as a result of the said suspension, which occurred both in the public as well as the private healthcare network, will tell whether the Slovenian Government and its bylaws struck the right balance.

\section{$5 \quad$ Back to the Hard Cases and How to Solve Them}

Briški and others (2020: 184-185) link hard cases of triage to severe overflows of medical capacities associated with mass accidents, such as earthquakes, floods or epidemics, in which difficult decisions of whom (not) to offer medical assistance are taken. Concerning ethical deliberations, included in extensive literature on the topic, they (2020: 185-187) refer to several possible criteria of medical treatment distribution, ranging from egalitarian, even purely procedural, to utilitarian orientations. Among the criteria, one can find, for example, the time-related criteria of the exact moment the patient was brought in to the healthcare facility, the somewhat early bird catches the worm approach, even lottery or draw, criteria of enhancing overall utility, like safeguarding the most years of life or, similarly, most quality years of life. Ethical deliberations, however, do not necessarily solve legal dilemmas associated with hard cases. Neither does the common health or constitutional law tool-kit. Imagine being faced with the dilemma of two patients in desperate need of the single available medical ventilator. The one who gets it survives. Going a step further, imagine being faced with a similar dilemma of a young patient, maybe a 
child, in desperate need of a medical ventilator that is already in use for urgent treatment of a much older patient suffering with additional medical conditions.

In severe cases of ex ante and expost competition of patients, only criminal law seems to be able to lead to relatively convincing solutions. According to Korošec (2016: 322-323), no man should take on the role of God, meaning no man should break the already established path of destiny. Referring both to Korošec and to the German Ethical Council, following the distinction between doing and allowing harm, or not killing but allowing to die, Briški and others (2020: 189) note that in cases of ex post competition, withdrawal of medical treatment cannot be deemed lawful but can in exceptional and morally justifiable cases lead to the exclusion of guilt. Different is the case of conflicting obligations, i.e. when medical practitioners can only save a limited number of lives, for example, due to the limited number of drugs, medical devices, etc., and thus not all patients in urgent need of treatment will receive it. In such cases the law cannot demand the impossible to occur, neither can it demand that the medical practitioner to justify why treatment only was offered to a particular person, thus saving only that patient's life to the exclusion of the other(s). Briški and others (2020: 189) consider such conduct to be in line with law, meaning the question of guilt does not become relevant.

However, it does not logically follow that merely because the medical doctor's conduct is deemed lawful that no other person can become criminally liable or liable for damages in cases in which the negative consequence, for example, relevant deterioration of health, death, can be ascribed to their conduct or omission. Such would, for example, be the cases of medical providers not guaranteeing enough staff or the State not guaranteeing enough emergency units, even if possessing the means to do so, whilst being familiar with the plausible risks of a medical capacities' overflow in cases of mass accidents, epidemics, etc. Such issues once again return us to the question of the State's positive obligations, a doctrine according to which the State is, as put by Tratar (2009: 101), liable not only for its active violations and the violations of its bodies or other public authorities, but also for violations resulting from its systemic failure to act when the law requires it to have done so. For such passivity, for example, in the field of healthcare organization, to be deemed unlawful, facts establishing it need to be objectively perceivable. From this perspective, the States' responses to the first, surprising and striking wave of the epidemic should be treated differently from later responses when much more was known about the virus 
(Mišič \& Strban 2020: 137). Put differently, the State can be liable only for reasonably foreseeable consequences of its (systemic) omissions. Eventually, similar questions concerning the State's positive obligations might surface in regard to the organization, availability and sufficient promotion of (voluntary) vaccination.

\section{Doctors' Calls for Immunity}

On October 19 2020, the Slovenian Doctors' Association addressed the Government with a call for doctors' temporary immunity against criminal and civil liability, claiming that the lack of doctors, nurses and other medical capacities due to the epidemic could lead to inappropriate healthcare and a surge in claims of professional mistakes resulting from a lack of sufficient resources.

From the legal point of view, the call, applying to all medical care providers, was unnecessary and, more importantly perhaps, completely misplaced. Neither criminal nor civil law adhere to strict liability doctrine in such cases, meaning that doctors would be legally responsible for the consequences of their acts or omissions even if no fault or intent could be ascribed. If, for example, a professional medical standard was violated, meaning a particular act or omission is deemed unlawful, no culpability or guilt is to be ascribed if the reason behind such violation cannot be ascribed to the medical practitioner. Žnidaršič Skubic (2018: 84) lists natural disasters, epidemics, wars and inappropriate organization of healthcare as examples that can lead to doctors being overwhelmed in performing their professional duties and thus exculpated in case of mistakes, low-quality treatment, etc. According to the author, strict liability can only rarely be found in tort law, that is, cases where deemed appropriate by legal and political reasons.

Arguments in favour of strict liability in healthcare include the following: a) it is difficult to establish professional mistakes due to doctors' professional solidarity, b) the lack of general standards of professional behaviour, c) the patient is the weaker party, d) the importance of protected interests [values]. Conversely, arguments against it include a) the sheer nature of the medical profession, in which the source of danger lies not in the profession itself but in the disease or medical condition, b) fear from defensive medicine, c) an excessive burden put on doctors (Žnidaršič Skubic, 2018: 85). Even if there exist arguments in favour of strict liability, arguments against it outweigh them making every violation of a medical standard or rule of 
conduct (both in criminal and) in civil law, subject to an assessment of all of the subjective circumstances of a particular case.

A critical consideration in this discussion is the fact that additional exposure to criminal and civil liability proceedings in times of a medical crisis would almost certainly contribute to the already problematic phenomena of defensive medicine, even without strict liability in place. In addition, from the doctor's point of view, it might seem less burdensome or stigmatizing if inappropriate medical care that he or she has provided is deemed as in accordance with the epidemically modified standard and thus lawful, rather than unlawful but as such, that no guilt can be ascribed (Mišič \& Strban, 2020: 758). The question is further examined in the final chapter of this contribution. The call for immunity would, if enacted, of course also encompass cases of triage, in which medical treatment was deferred or was not provided which led to a relevant deterioration of the patient's health or even death.

\section{$7 \quad$ Law and Medicine: Friends or Foes?}

The final chapter of the contribution tries to set the somewhat illusive line between law and medicine concerning (hard cases of) triage. On the one hand, law, be it a legislative act or a regulation, cannot assume the professional role of medicine. Numerous references to professional or other legal standards or vague legal terms, calling for every time concretisation, found in, for example, the Medical Services, Health Services or Patients' Rights Act, illustrates how the law relinquishes aspects of its normative power so as to be able to adapt and appropriately govern all future cases.

The same applies to Article 190 of the Slovenian Criminal Code, ${ }^{18}$ prohibiting negligent medical treatment. Article 190, for example, directly refers to medical sciences and profession. Since acts serve the masters of generality and abstraction, they need to be able to cope with concrete cases, thus permitting other disciplines to determine the scope of legally sound conduct, either by means of drafting specific professional rules or by means of drafting professional standards. However, when doing so, all disciplines, medicine included, and representative bodies, ought to respect constitutional and other basic values, safeguarded by a given domestic and

\footnotetext{
18 Official Gazette of the RS, No. $15 / 12$ to $95 / 21$.
} 
international legal order. From this perspective, the values of human dignity and safety, personal autonomy protection, equal treatment, etc., come into force, making it difficult for medical professional standards or rules of conduct to depart from the said provisions of the Patients' Rights, Medical Services or Health Services Act. If they did so, they would have taken on the role of the general legislator as the sole body competent for enacting heteronomous rules and obligations for patients, doctors, other medical staff and medical providers.

Put differently, if medical professions' autonomous legislation were given the normative power of an act, then such rules could, for example, prescribe criteria of distribution of scarce medical services, equipment, etc., that would run afoul of the basic constitutional principle of equality. Age or sex could, for example, become the solely applicable criteria, meaning that particular acts or omissions concerning triage, that would follow such criteria, would be considered lawful even if they did not follow the criteria of necessity or urgency, grounded in the entirety of the patient's medical condition. In such cases, no questions of culpability or guilt, even if not being ascribed to medical practitioner's conduct (for example, due to collision of conflicting obligations), would even surface. From this perspective, every professional rule or standard has to be in accordance with the act, giving part of its normative power to a particularized legislator, be it the medical chamber, doctors' association, professional body under a particular branch of medicine, and the constitution. This is true even if this means we have now come full circle, finding ourselves where we began this discussion, that is, with the inalienability of the right to life and the categorical approach to the protection of human dignity and private autonomy.

It once again seems it is left to general institutions of criminal law, such as necessity as justification or as defence, and the conflict of duties, to resolve the hard cases of triage where one or several lives are sacrificed in order to save lives of others. Especially in the hardest cases, where patients, sharing completely the same outlooks of recovery, compete for scarce medical services, equipment, etc., and it is only prohibited personal circumstances of distinction, such as age, sex, family status, that actually distinguish one from the other. Briški and others (2020: 190), however, note that recommendations (not rules) drafted either by ethical or other professional committees on how to handle hard cases of triage could allow for a better oversight 
of future and past cases, thus making decisions more transparent and just in the eyes of the general public.

\section{$8 \quad$ Concluding thoughts}

Like elsewhere in Europe and the World, the Covid-19 epidemic caught the Slovenian parliament and government, as well as medical providers and practitioners, off guard. This was true both in regard to their normative as well as their operational readiness for a medical crisis. It seems that for the very first time, hard cases of ex ante and expost triage or patients' competition for medical care begun to flow from textbooks and into reality in a constant current of fear and complete ignorance of things to come.

It seems such a crisis was needed in order for lawyers (and possibly medical doctors) to finally start to contemplate and critically discuss the somewhat difficult relationship between law and medicine in cases of involuntary end of life decisions. What we have come away with so far, at least in domestic scholarship, are not catchall answers but key questions on human dignity, private autonomy, value of life, etc., that should have been posed years ago. The authors hope that this article, trying to overcome the purely national debate on the Patients' Rights Act and other applicable legislation, posed at least some of them and will, from this point of view, trigger a debate on the future of legal regulation of (medical) triage. Not only for the next epidemic, natural disaster or major car crash, but for all cases when patients will have to compete for scarce medical services or medical equipment (although hoping this will never really happen).

\section{References}

Briški, L. et al. (2020) Koga reševati v času pandemije? Etični in kazenskopravni vidiki triaže, Revija za kriminalistiko in kriminologijo, 71(3), pp. 183-193.

Gurgel, D.S. (2000) Die Entwicklung des Vertragsärztlichen und Vertragszabnärztlicher Vergütungssystems nach dem zweitem Weltkrieg (Aaschen: Schaker Verlag).

Ivanc, B. (2011) Komentar 51. člena Ustave Republike Slovenije, in: Šturm, L. (ed.), Komentar ustave Republike Slovenije. Dopolnitev A (Ljubljana: Fakulteta za državne in evropske študije), pp. 815873.

Korošec, D. (2016) Medicinsko kažensko pravo (Ljubljana: GV Založba).

Korošec, D. et al. (2016) Komentar 3. člena ZPacP, in: Balažic, J. (et al.) (eds.), Zakon o pacientovih pravicah (ZpacP) s komentarjem (fragment) (Ljubljana: GV Založba), pp. 49-55. 
Mišič, L. \& Strban, G. (2021) Functional and Systemic Impacts of Covid-19 on European Social Law and Social Policy, in: Hondius, E. (et al.) (eds.) Coronavirus and the Law in Europe (Cambridge: Intersentia), pp. 973-988.

Mišič, L. \& Strban, G. (2020) Triaža: kjer se pravo in medicina razideta?, Pravnik, 137(11-12), pp. 747-808.

Mišič, L. (2020) Metamorfoze pacientovih pravic v kriznih časih, Pravna praksa, 39(45), pp. 1-6 (I$\mathrm{VI})$.

Pavčnik, M. (2007) Teorija prava. Prispevek k razumevanju prava, 3. spremenjena in dopolnjena izdaja (Ljubljana: GV Založba).

Strban, G. (2005) Temelji obveznega zdravstvenega zavarovanja (Ljubljana: Cankarjeva založba).

Tratar, B. (2009) Doktrina pozitivnih dolžnosti držav po EKoČP, Dignitas, (41-44), pp. 81-102.

Žnidaršič Skubic, V. (2018) Civilno medicinsko pravo. Iz̧brane teme (Ljubljana: Uradni list Republike Slovenije). 
